\title{
Strength, Rapid Chloride Penetration and Microstructure Study of Cement Mortar Incorporating Micro and Nano Silica
}

\author{
Rishav Garg ${ }^{1, *}$, Manjeet Bansal $^{2}$, and Yogesh Aggarwal ${ }^{3}$ \\ ${ }^{1}$ Research Scholar, I.K. Gujral Punjab Technical University, Kapurthala-144603 (India) \\ ${ }^{2}$ Giani Zail Singh Campus College of Engineering \& Technology, Bathinda-151001(India) \\ ${ }^{3}$ National Institute of Technology, Kurukshetra-136119 (India) \\ *E-mail: rishavgarg77@yahoo.com
}

doi: $10.20964 / 110455$

Received: 10 February 2016 / Accepted: 27 February 2016 / Published: 1 April 2016

This paper presents the strength, rapid chloride penetration and microstructure study of cement mortar incorporating micro-silica (MS), nano-silica (NS) and micro-silica with optimized content of nanosilica (MS+NS) as a partial replacement of cement. The hardened properties of the mortar such as compressive strength and split tensile strength of all the specimens has been determined at the age of 28, 56, 90 and 180 days. Quadratic model and ANOVA analysis has been carried out to determine the optimized content of NS. Further, durability properties of all the specimens have also been determined in terms of carbonation test. The microstructure of the specimens has been determined by SEM-EDX studies. The results reveal the enhanced strength, durability and improved microstructure of mortar specimens with proper combination of micro and nano silica resulting in better performance as compared to conventional specimens.

Keywords: Microstructure, rapid chloride penetration, strength, nano-silica, micro-silica

\section{FULL TEXT}

(C) 2016 The Authors. Published by ESG (www.electrochemsci.org). This article is an open access article distributed under the terms and conditions of the Creative Commons Attribution license (http://creativecommons.org/licenses/by/4.0/). 